\title{
The Fiction of the Irish in England a
}

Tony Murray

The Oxford Handbook of Modern Irish Fiction

Edited by Liam Harte

Print Publication Date: Oct 2020

Subject: Literature, Literary Studies - 19th Century, Literary Studies - Fiction, Novelists, and

Prose Writers, World Literature

Online Publication Date: Oct 2020 DOI: 10.1093/oxfordhb/9780198754893.013.43

\section{Abstract and Keywords}

This chapter examines the way in which Irish fiction has engaged with one of the most persistent features of Irish history over the last 200 years, the migration of its people to England. In doing so, it highlights how novels and short stories have played a role in mediating the experiences of Irish migrants in England and how writers have used fiction to fashion a means by which to articulate a sense of Irish cultural identity abroad. The analysis demonstrates how, over two centuries of fiction about the Irish in England, there has been a discernible shift of emphasis away from matters of primarily public concern to those of a more private dimension, resulting in works that illuminate latent as well as manifest features of the diasporic experience and its attendant cultural allegiances and identities.

Keywords: Ireland, fiction, the Irish in England, Anglo-Irish, Irish women in England, second-generation identity

IF emigration is 'a mirror in which the Irish nation can always see its true face', ${ }^{1}$ such a mirror is by no means flawless. It has cracks, abrasions, and missing pieces which distort our understanding of how one of the most persistent features of Irish history has affected its people's perception of themselves. This is nowhere more evident than in the country's literary reflections on migration. This is particularly true in regard to one of its nearest neighbours, England, where the presence of the Irish has long been freighted with political and cultural difficulties due to the troubled colonial relationship between the two countries. Unsurprisingly, therefore, authors have used stories about the Irish in England to make polemical interventions in broader historical and political debates. Prose fiction, however, has a unique capacity to mediate the deeply textured interplay between the public and private aspects of the migrant experience and, in recent times, its primary focus has been the particularities of individual immigrants' material circumstances, social interactions, and psychological states. This chapter aims to demonstrate how, over two centuries of fiction about the Irish in England, there has been a discernible shift of emphasis away from matters of primarily public concern to those of a more private nature, result- 
ing in works that illuminate latent as well as manifest features of the diasporic experience and its attendant cultural allegiances and identities.

There is insufficient space here to provide a fully comprehensive survey of the fiction of the Irish in England, and many novels and short stories on the topic by established Irish writers are necessarily excluded. ${ }^{2}$ Viewed as a whole, this literary corpus lends itself to a (p. 462) variety of potential angles of analysis, but three prevalent and interrelated themes provide a critical framework for the examination that follows, the focus of which will necessarily be on fiction produced by writers who are Irish by birth or descent. In the first section, I discuss works by Anglo-Irish authors whose cultural duality afforded them an interstitial perspective on the societies of both countries. In the nineteenth century, many of these authors used fiction to examine both the attractions and the limitations of English society for a class that steadily lost its political power and social privilege in Ireland after the Act of Union of 1800. In the twentieth century, as this class's status in the wake of Irish independence became even more anomalous, Anglo-Irish writers in England moved their attention away from political preoccupations to the broader and more complicated personal predicaments in which such migrants found themselves. The second section deals with the specific experiences of Irish women in England, who migrated there in larger numbers than men from the late nineteenth century onwards. Again, a public-to-private transition is apparent as we move from nineteenth-century works motivated by increasingly (proto-)feminist convictions to works of the later twentieth century, which, while no less politically aware, concentrate more on how the individual experience of displacement impacted on women's personal sense of identity. The final section addresses works that centre on second- and later-generation Irish migrants in England, most of which have been written in the last hundred years. Here, a similar change of emphasis is apparent, insofar as fictional accounts from the first half of the twentieth century tend to focus on communal questions of class and religious identity, whereas those from the post-war era are more preoccupied with their characters' individualized negotiations of race and ethnicity.

While the earliest texts examined here date from the early 1800s, novels about the Irish in England had appeared from as far back as the 1660s. Most of these were picaresque romances and as such do not qualify for inclusion within the thematic framework of this chapter (or indeed the temporal scope of this volume), but their existence proves that the subject of migration to England was a distinct feature of the earliest stages of the Irish novel's evolution. ${ }^{3}$ It should also be noted that the presence of Irish characters in England has a long lineage in the work of non-Irish writers, a topic worthy of a separate study. ${ }^{4}$ The Irish experience in Scotland is sufficiently distinctive in cultural and religious terms to merit discrete treatment also, although the same cannot be said of the Irish experience in Wales, which has featured little in fiction. ${ }^{5}$ Given the city's historical (p. 463) attraction for generations of Irish writers, novels and short stories set in London have dominated the canon, although a significant proportion feature urban locations of Irish settlement elsewhere, notably Lancashire and the West Midlands, while a handful represent the less common experience of Irish migrants in rural English settings. 


\section{Absence and Alienation: Anglo-Irish Preoccu- pations}

Most histories of the Irish novel identify Castle Rackrent (1800) by Maria Edgeworth (1767-1849) as a defining moment in its development. Twelve years later, the same author published The Absentee (1812), which explores the anomalous position of the AngloIrish in English society after the Act of Union. A central and sometimes didactic theme in Edgeworth's work is the neglect by the ruling Anglo-Irish Ascendancy of their obligations in regard to their estates and dependents in Ireland. As the title of the novel makes clear, The Absentee deals with an especially nefarious aspect of this subject. Lord Clonbrony, the landlord in question, has been living comfortably in London for some years on the proceeds of his Irish estate. His wife, however, struggles to establish herself in cosmopolitan high society and is ridiculed by her female English peer group for attempting to ingratiate herself with them. Despite throwing an extravagant party which impresses them, her unsuccessful endeavours to disguise her use of Hiberno-Irish idioms ensures that she continues to be regarded as an outsider.

By anchoring a novel about absentee landlordism in England, Edgeworth is able to provide a dual commentary on Anglo-Irish affairs. She not only demonstrates how the Irish peasantry are objectified by the Anglo-Irish from afar but also how the latter are themselves objectified in turn by the English in their midst. Meanwhile, a generational disjuncture is apparent when Lady Clonbrony's son becomes increasingly alienated from what he regards as his mother's 'Londonomania' ${ }^{6}$ and urges her to moderate her obsession with the city. Unlike his parents, who have little interest in Ireland, Lord Colambre is anxious to learn more about the economic and social consequences of their neglect of their Irish estates, eventually persuading the family to return to live there. The novel suggests, therefore, how commitment to property and nation, while undermined by the migration of one generation, can, under certain circumstances, be revived by the concern and actions of a subsequent generation.

The Wild Irish Boy (1808) by Charles Maturin (1780-1824) is generally considered one of the author's less successful novels, but its attention to absenteeism is noteworthy if only because it pre-dates Edgeworth's text. Ormsby Bethel is the English-born son of an (p. 464) Anglo-Irish landlord leading a dissolute and reckless life in London. ${ }^{7}$ When he visits his ancestral home in Ireland, he is struck not so much by the actual absence of the landlord class as by 'a kind of mental absenteeism pervad[ing] [the] country'. ${ }^{8}$ However, his disillusion with the behaviour of both the Catholic peasantry and the Protestant Ascendency undermines any suggestion that he might play the mediating role in Anglo-Irish affairs that Colambre does. In this regard, the novel differs radically from The Absentee, and, by focusing more on Ormsby's conflicted patriotism, anticipates questions of cultural allegiance more associated with much later novels about the second-generation Irish experience in England. By contrast, when absentee landlord Gerald Blount visits his estates for the first time in John Banim's (1798-1842) The Anglo-Irish of the Nineteenth Century (1828), his prejudices about the Irish poor evaporate, prejudices acquired years before 
during a visit he made to the Irish ghetto of St Giles in London, which carried a stigma of contagion and criminality propagated by hostile coverage in the English press. ${ }^{9}$ Banim's novel, by implication, raises an intriguing question about the extent to which long-established anti-Irish racism in English society might have prejudiced the attitudes of absentee landlords to their dependants back in Ireland. ${ }^{10}$

'Kate Connor' (1842), a short story by Mrs S. C. Hall (Anna Maria Fielding, 1800-81), demonstrates that the morality of landlord absenteeism and its continuing political ramifications were still topical well into the nineteenth century. ${ }^{11}$ Here, a young peasant woman makes a lone and perilous journey to England to appraise her landlord's daughter (and erstwhile confidante) about her family's recent eviction and the mistreatment of tenants by the land agent. Very much in the spirit of Edgeworth, this results in the landlord setting an example to his peers by immediately returning to his estate. However, Kate's unlikely journey across the Irish Sea is a rather cumbersome and unconvincing narrative device for illustrating how good Anglo-Irish relations might be maintained.

By the late nineteenth century, when the worst vestiges of absenteeism were largely a thing of the past, there was a shift of emphasis in the literature away from such didactic concerns towards the more personal preoccupations of Anglo-Irish characters in England. One consequence of this is that anomalies and ambiguities about the status and role of the Irish landlord class in English society tend to be explored in more psychologically nuanced ways. George Moore's (1852-1933) A Drama in Muslin (1886) is a good example of how the genre of the absentee novel morphed into a more modernist examination of how a younger generation of Anglo-Irish migrants were beginning to seek alternative futures to the redundant trajectories mapped out for them by their parents. Significantly, Alice Barton's eventual form of escape, as well as being a physical migration to London, (p. 465) is one of class migration, since Moore's heroine chooses to marry a doctor against her aristocratic parents' wishes. Another example is provided by Robert Thorne (1907) by Shan F. Bullock (1865-1935). Despite being born in Devon, the eponymous hero has an Irish mother and is closely based on the author's own life in England, where he worked as a civil service clerk after emigrating from Fermanagh in $1883 .{ }^{12}$ Like Alice Barton, Bullock's fictional alter ego transgresses a cultural divide by building a close friendship with Mrs Flynn, his Irish Catholic landlady. This is a rare example of a novel which, by portraying the relationship between a second-generation Irish Protestant and an Irishborn Catholic in England, highlights commonalities between their respective cultural backgrounds which might not otherwise be immediately apparent.

The narrative approach of Robert Thorne also represents a self-conscious move away from the realist fiction of the nineteenth century to the more self-reflective prose of the subsequent century. The novel is prefaced by a letter from Bullock, posing as the editor of Thorne's autobiography, in which he apologizes to Thorne for any 'erasures-interpolations-additions'13 in the text. He even goes so far as to insert a number of footnotes questioning the veracity of certain factual details and criticizing Thorne's prose style. In the first of these, Bullock remarks that 'It is necessary to keep in mind, whilst reading his record, that Thorne was half Irish by birth.' ${ }^{14}$ This may just be a tongue-in-cheek jibe at 
Thorne's Irish background, but it might also be an indication of how Bullock (the author rather than the fictionalized editor) was prepared to question the efficacy of his own testimony, thus anticipating the postmodern playfulness of later London Irish novels such as Dónall Mac Amhlaigh's (1926-89) Schnitzer O’Shea (1985) and Robert McLiam Wilson's (1964-) Ripley Bogle (1989).

The afterlife of the Anglo-Irish Ascendancy in Ireland's literature has been most pronounced in the genre of the Big House novel, which began to emerge during the period of the land reforms of the late nineteenth century and has continued with remarkable resilience up to the present day. One of its most accomplished exponents was Elizabeth Bowen (1899-1973), who came from such a background herself. Bowen lived in the south of England for most of her life and it was arguably the objective reflection afforded by this physical distance from Ireland that enabled her to capture the nuances of Anglo-Irish life so perceptively in her second novel, The Last September (1929). Fictional works portraying Irish characters in Bowen's country of adoption tend to mirror this sense of distanciation, with plotlines which entail them making journeys back to Ireland to maintain their sense of Irishness rather than pursuing this through Irish associations in England. One such example is A World of Love (1955), in which Antonia Montefort makes regular visits to her country house in Ireland. Another is Bowen's great Second World War novel, The Heat of the Day (1948). Stella Rodney's life in London is lived in a constant state of contingency, not only because of the Blitz but also because of the indeterminate nature of her relationships with two male spies with whom she is romantically involved. She is able to periodically escape her circumstances, however, by visiting (p. 466) Mount Morris, her family estate in Ireland. In contrast to London, the estate offers Stella a seemingly tranquil and stable retreat in neutral Ireland where, as she reflects, the house 'rose to the surface in her, as though something weighting it to the bottom had let go' ${ }^{15}$ Here, too, she is able to reconnect with her childhood memories and find time to reconsider the complications of her personal life in England.

The plotlines of The Heat of the Day and A World of Love both exemplify a significant evolution in the fictional representation of Anglo-Irish identities. Whereas in much nineteenth-century fiction, London provides Anglo-Irish protagonists with a haven from the turmoil of their Irish estates, by the mid-twentieth century, Ireland has become a sanctuary and a place of refuge for their beleaguered descendants. This trend is also apparent in 'Sunday Afternoon' (1941), one of Bowen's few short stories about the Anglo-Irish, in which Henry Russel visits family friends in County Dublin after being bombed out of his flat in London during the Second World War. Bowen juxtaposes the horrors of life in London at this time with the Edwardian-like calm of a country house belonging to the AngloIrish Vesey family. By doing so, she highlights the gulf that has opened up between the anachronistic lives and worldview of the Anglo-Irish and the sterner realities of war-torn England. The dramatic tension of the story ultimately pivots around the question of migration and in particular Mrs Vesey's young niece, Maria. Here is a young woman who feels so stifled by her family circumstances that she is prepared, against the advice of Russel, to move to London and risk the Blitz for a 'new catastrophic outward order of life' ${ }^{16}$ While the obverse of Antonia Montefort's and Stella Rodney's motivation, Maria's 
decision reflects a long-established 'push' factor for Irish female migrants, which is examined in more detail in the next section.

Like Elizabeth Bowen, with whom she became a close friend in later life, Iris Murdoch (1919-99) was an only child, born into an Anglo-Irish Protestant family in Dublin, who grew up in England and worked in Whitehall during the Second World War. The Irishness of Murdoch's fictional Irish characters in England is, like Bowen's, often only alluded to tangentially, which possibly reflects Murdoch's life-long ambivalence about her own national identity. ${ }^{17}$ In her partially autobiographical first novel, Under the Net (1954), Jake Donaghue has somewhat indeterminate Irish ancestry by way of his sidekick, the Irishborn Finn (Peter O'Finney), who he describes as 'a sort of remote cousin of mine, or so he used to claim, and I never troubled to verify this'. ${ }^{18}$ In its existentialist preoccupations and low-key comedy, Under the Net shares commonalties with two important London Irish novels. On the one hand, it looks back to Samuel Beckett's (1906-89) Murphy (1938), a copy of which Jake possesses and the plots of which are mirrored in their respective protagonists' jobs as hospital orderlies. On the other, it anticipates the trajectory of Anthony Cronin's (1928-2016) The Life of Riley (1964), as its (p. 467) solipsistic anti-hero adopts a bohemian lifestyle, only to end up alone and chastened on the streets of Hampstead. The ambiguous identity of Irish characters in Murdoch's work is also evident in Pattie O'Driscoll, the housekeeper in The Time of the Angels (1966). Here is an early example of a mixed-race Irish character which signals the beginning of a shift of emphasis in Irish fiction in England to the more complex questions of identity discussed in the final section of this chapter. ${ }^{19}$

William Trevor (1928-2016) might be considered the inheritor of Bowen and Murdoch's mantel. Born into a middle-class Protestant family in Cork, he moved to London in 1952 and once described his true sense of home as being somewhere between Holyhead and Dun Laoghaire, a remark that accords with Roy Foster's characterization of Bowen as feeling 'most at home in mid-Irish Sea'. ${ }^{20}$ In the early phase of his career, Irish characters in Trevor's novels set in England are generally unattractive figures, such as the blackmailer Mr Studdy in The Boarding House (1965) or the sexual predator Septimus Tuam in The Love Department (1966). By the early 1970s, the appearance of more complex and sympathetic characters, such as Alban Roche in Miss Gomez and the Brethren (1971), reflects an increasingly nuanced approach to Irishness which by Felicia's Journey (1994) had developed into what one critic described as Trevor's 'most comprehensive study to date of an Irish sensibility, trying-and failing - to make sense of England'. ${ }^{21}$ As a writer renowned for his skilful treatment of the anomalous position of the Anglo-Irish in Ireland, the political and moral dilemmas that Irish people in England faced during the Northern Ireland Troubles offered Trevor similar subject matter, albeit in an altogether different context. Short stories such as 'Another Christmas' (1978) and 'Being Stolen From' (1981) clearly demonstrate how sensitively he was able to handle this. They also reveal how the complexities of Anglo-Irish political relations, so pronounced in early nineteenth-century Irish literature, were still evident at the end of the twentieth, albeit treated in less moralizing and more psychologically sophisticated ways. 


\section{Refuge and Opportunity: Women's Journeys}

As one of Ireland's closest neighbours, England has historically provided Irish women migrants with a readily accessible place of opportunity and a physical and emotional haven, albeit a sometimes uneasy one. One of the earliest fictional renditions of this (p. 468) theme occurs in Ann Hamilton's The Irishwoman in London (1810), an epistolary account of Ellen O'Hara, a young woman who flees an unhappy marriage in Monaghan to live incognito in London. Despite being reclaimed and repatriated by her husband, she opts once more to pursue the romantic opportunities offered by the metropolis after his death. Revealingly, it transpires that her mother had made a similar journey some years earlier when she eloped with her fiancée, something which indicates that such experiences were not unusual for Irish women of means, even in the pre-Victorian period. ${ }^{22}$

If moving to England, and to London in particular, in the nineteenth century was a drastic but effective way for young Irish women to assert their independence, it was also seen as a necessity by many aspiring writers keen on pursuing a career in literature and the arts. ${ }^{23}$ Most English-based Irish female novelists of this era, such as Charlotte Riddell (1832-1906) and Emily Lawless (1845-1913), came from well-to-do Protestant backgrounds, the largest cohort being daughters of Church of Ireland ministers, such as Selina Bunbury (1802-82), who moved to Liverpool in 1830, and the highly prolific Cork-born L. T. Meade (pseudonym of Elizabeth Thomasina Meade Smith, 1844-1914), who moved to London in 1874. Notable Irish Catholic novelists whose careers followed the same course include M. E. Francis (pseudonym of Mary E. Sweetman, 1859-1930), who lived in Lancashire and Dorset, and Katharine Tynan (1859-1931), who lived for a large part of her life in London. What is most distinctive about the treatment of emigration to England in these authors' works is the correlation between the 'push' motivations of unhappy or abusive marriages at home and the 'pull' motivations of potential affairs and careers abroad.

Unsurprisingly, perhaps, the fiction produced by such writers had a strong autobiographical aspect. An early example of this is Molly Carew (1879) by Elizabeth Owens Blackburne Casey (1848-94). While essentially a conventional romance and product of the popular Victorian genre of sensationalist fiction, the novel's treatment of the difficulties an Irish female migrant faces in the male-dominated literary world of London makes it a precursor to works by better-known authors such as Riddell, whose A Struggle for Fame, her first novel, about an Irish woman in London, did not appear until $1883 .{ }^{24}$ Its central character, Glenarva Westley, based to some extent on Riddell herself, faces deep prejudice from London publishers due to her gender. While it has been criticized for occluding the Irish dimension to its heroine's character, the novel is, nevertheless, (p. 469) a meticulously crafted record of the practical day-to-day hurdles encountered by an ambitious but unfairly disadvantaged female writer of the time. ${ }^{25}$

By the latter end of the nineteenth century, such novels had become more self-consciously feminist in outlook. ${ }^{26}$ Sarah Grand's (pseudonym of Frances Clarke McFall, 1854-1943) semi-autobiographical New Woman novel, The Beth Book (1897), for instance, is an ac- 
count of a middle-class northern Irish woman whose burgeoning self-awareness, in the wake of a disastrous marriage in Yorkshire, fuels her ambitions to become a writer in London. Crucially, Grand conveys how the city not only provides Beth with the practical opportunity to pursue her chosen career but also the freedom and sensibility of mind necessary to write in the first place. Her rambles through London's streets teach her 'to appreciate the wonder and beauty of the most wonderful and beautiful city ever seen', as her 'eyes grew deep from long looking and earnest meditating upon it'. ${ }^{27}$ This description contrasts starkly with representations of London as corrupt and heathen in Irish cultural discourse of the late nineteenth and early twentieth centuries. There was considerable moral and religious anxiety at this time about the potential dangers to which young London-bound women might be subjected, and this is reflected in fiction. An early example is the short story, 'A Psychological Moment at Three Periods' (1894), by George Egerton (pseudonym of Mary Chavelita Dunne, 1859-1945). It concerns an Irish woman in London who is subjected to the attentions of a sexual predator and is notable for the way it employs the early techniques of literary modernism to convey the fragmented impressions and intuitions of its heroine at a moment of personal jeopardy. ${ }^{28}$ Journeying deeper into this fictional territory, the threat of what was referred to as the 'white slave trade' (sex trafficking in today's terms) is flagged up in two early twentieth-century novels about vulnerable young Irish women in English cities. Rosa Mulholland's (1841-1921) The Tragedy of Chris: The Story of a Dublin Flower Girl (1902) follows a young woman who travels to London in order to rescue her friend who has fallen into a life of prostitution. While the novel successfully captures the sense of culture shock experienced by its protagonists in London, it has been criticized for eliding 'the stark reality of the economic choices faced by poverty-stricken Irish women ${ }^{29}$ who had no option but to migrate there. The eponymous protagonist of The Story of Mary Dunne (1913) by M. E. Francis, meanwhile, escapes from the morally claustrophobic atmosphere of her rural Irish community after being criticized by her parish priest for associating with men other than her fiancée, only to be kidnapped into prostitution in Liverpool.

(p. 470) By the mid-twentieth century, writers had developed an increasingly sceptical attitude to the supposed attractions of new lives in England and the escape trope took on a more tarnished appearance as a result. A job in a London literary publishers' office is just one of a series of short-term and unfulfilling positions for the heroine of Rose Forbes: The Biography of an Unknown Woman (1937) by George Buchanan (1904-89). Having fled her hometown of Bangor in Northern Ireland after the tragic drowning of her fiancée, Rose is initially attracted to an unnamed English seaside resort. She then drifts into a series of unsatisfactory affairs with men she meets in London, before finding herself trapped in a marriage with a man she does not love. In this regard, she is representative of a number of female characters in interwar Irish fiction who live unfulfilled lives on the fringes of English society, such as the prostitute Celia Kelly in Beckett's Murphy and the eponymous housemaid in 'Bridget Kiernan' (1928) by Norah Hoult (1898-1984).

Perhaps the best-known example of a novel about the disappointments for Irish women which result from romantic adventures in England is the ironically titled Girls in Their Married Bliss (1964). By the opening of this, the third part of Edna O'Brien's (1930-) The

Page 8 of 20

PRINTED FROM OXFORD HANDBOOKS ONLINE (www.oxfordhandbooks.com). (C) Oxford University Press, 2018. All Rights Reserved. Under the terms of the licence agreement, an individual user may print out a PDF of a single chapter of a title in Oxford Handbooks Online for personal use (for details see Privacy Policy and Legal Notice). 
Country Girls trilogy, the two young heroines, Kate Brady and Baba Brennan, are both in dysfunctional relationships in London and have resorted to extra-marital affairs in an attempt to escape their unhappiness. For Baba, the more psychologically robust of the two, the nefarious effects of this are contained. Kate's sexual exploits, however, are more detrimental to her well-being. She is not as emotionally well-defended as Baba and, when an affair leads to the potential break-up of her marriage, her sense of guilt and fear of sudden abandonment lead her into increasingly self-destructive behaviour. Despite its portents, it still comes as a shock when her eventual suicide is confirmed in an epilogue to the trilogy, published in 1986. Similar conflicts are apparent in O'Brien's fifth novel, Casualties of Peace (1966). Although artist-protagonist Willa McCord avoids her compatriot's fate by leaving an unhappy marriage before it is too late, she ironically meets her end as the inadvertent victim of a similarly dysfunctional relationship between a London Irish couple with whom she is lodging.

That London Winter (1981) by Leland Bardwell (1922-2016) is another autobiographical novel about an Irish woman's unsuccessful attempt to find emotional escape and satisfaction through the pursuit of an extra-marital affair. Like Bowen and Murdoch, Bardwell was an Irish-born Protestant who was educated in England. Her novel is set in late 1950s London and traces the emotional decline of Nina as she resorts to heavy drinking and an increasingly debauched lifestyle to assuage her unhappiness. In contrast to Edna O'Brien's heroines, however, Nina is part of a more middle-class and trendy left-wing social set that mixes with a far wider cross-section of London's population, including other migrant groups such as Cypriots, Russians, and Tamils. The novel is not as technically accomplished as O'Brien's but nevertheless provides a rare insight into the consequences for an emotionally troubled Irish woman of mixing in the ostensibly more liberated but still male-dominated bohemian milieu of post-war Soho. ${ }^{30}$ Nina's (p. 471) experiences in That London Winter can also be read to some extent as the unadorned flip-side to the somewhat glorified male version of this world described in Anthony Cronin's The Life of Riley and Iris Murdoch's Under the Net.

It is telling that Bardwell did not publish her novel until more than two decades after it is set. This may be related to the fact that by the 1980s, Irish women writers, with the advent of second-wave feminism, were beginning to have an even bigger impact on Irish literature than in the late nineteenth century. Fiction by and about Irish women in England played an important role in this development. This was particularly true in relation to works by a new generation of mainly Catholic Northern Irish writers in England whose fiction directly or indirectly confronted the trauma of the Troubles. Notable texts include Anne Devlin's (1951-) short story, 'Five Notes After a Visit' (1986), and Deirdre Madden's (1960-) novel, One by One in the Darkness (1996). Fiction by Northern Irish Protestant women is less common and until relatively recently has been somewhat overlooked by critics. Linda Anderson's (1949-) Cuckoo (1986) is a case in point. The novel is set in London in the early 1980s and concerns Fran McDowell, a Belfast Protestant, coming to terms with the double trauma of a forced abortion and a personal bereavement due to the Troubles. ${ }^{31}$ Furthermore, Fran finds herself in the predicament of raising a mixed-race daughter as a single mother at a time of multiple political crises, including the Irish re-

Page 9 of 20

PRINTED FROM OXFORD HANDBOOKS ONLINE (www.oxfordhandbooks.com). (c) Oxford University Press, 2018. All Rights Reserved. Under the terms of the licence agreement, an individual user may print out a PDF of a single chapter of a title in Oxford Handbooks Online for personal use (for details see Privacy Policy and Legal Notice). 
publican hunger strikes, the Falklands War, and the cruise missile protests. It is her involvement with the last of these issues, however, which finally provides her, in the shape of the Greenham Common women's peace camp, with a dependable, if surrogate, sense of home and security after the emotional disturbances she has experienced. Fran's attempt to deconstruct her past through a series of personal and political present-day relationships involves a complex meditation on the interconnectedness of trauma, grief, sexuality, nationality, and memory. The formal structure and tone of the novel mirror the fragmented legacy of the protagonist's past, incorporating numerous time shifts, multifocal narrative voices, and switches from prose to drama to diary-writing. It is significant that the last of these forms, the performative act of writing itself, provides Fran with a means of reconciling a conflicted past in Ireland with a complicated present in England-an outcome that echoes that of her London Irish forebears of the late nineteenth century.

Eimear McBride's (1976-) second novel, The Lesser Bohemians (2016), subverts the longestablished narrative of the unhappy Irish woman seeking emotional refuge through escape to England. Set in north London in the mid-1990s, it centres on Eily, an eighteenyear-old Irish drama student, who, by revealing her emotional vulnerability during the course of an extended affair with an older English actor, assuages the legacy of a traumatic childhood. The novel's critical acclaim derives in part from the manner in which it employs a variation on the uncompromising neo-modernist prose style of McBride's multiaward-winning first novel, A Girl is a Half-formed Thing (2013). (p. 472) This allows its author to mediate her protagonist's sometimes exhilarating, sometimes disconcerting disjunctions between thought, speech, and sexual expression. Eily's experience of migration is notable for the way she embraces London and the physicality of its streets and buildings with the same sense of abandon and adventure she does her love affair. As such, The Lesser Bohemians is markedly different to many earlier portrayals of young Irish women in England, where the city is often perceived as overwhelming or threatening for the newcomer. McBride can also be seen as representative of a new generation of Irish women writers who are no longer cowed by the overbearing influence of patriarchal Catholic values but are writing with a self-confident vigour reminiscent of the New Woman writers of the fin de siècle, and bringing fresh perspectives to bear on the fiction of the Irish in England.

\section{Assimilation and Ambivalence: Generational Dimensions}

Since the early twentieth century, a growing body of prose literature by the descendants of Irish migrants in England has emerged. ${ }^{32}$ Whether published as fiction or as autobiography, such texts provide a fertile source for exploring how the cultural identities of second- and later-generation migrants are articulated and narrativized over time and place. For male writers, this is more commonly explored in autobiography than in fiction, while the reverse is true for female writers. ${ }^{33}$ Sociological research has found that the descendants of Irish migrants sometimes claim contrary ethnic positions according to different 
circumstances. ${ }^{34}$ By threading different life events together through narrative, autobiographical fiction can be a productive site for examining how writers and their characters employ these forms of 'contingent positionality' 35 to negotiate and mediate testing questions of identity and allegiance.

Bill Naughton (1910-92) was born in Ireland but raised from the age of four in the Lancashire mill town of Bolton during the interwar years. He is best known for the novel Alfie (1966), which became an iconic film about 1960s London, and also wrote a critically (p. 473) acclaimed series of memoirs in his later years. ${ }^{36}$ Earlier in his career, Naughton published One Small Boy (1957), a semi-autobiographical novel about a child of immigrant Irish parents in the north of England. Significantly, religion plays a more dominant role than ethnicity in the formation of its young protagonist's identity. This is particularly true in regard to Michael M'Cloud's growing awareness of his sexuality and how this awareness is self-policed by his strong sense of Catholic guilt. This becomes apparent when Michael describes the street games he plays with his non-Catholic peers and how their guilt-free appetite for mischief not only contrasts with his own reticence but also with his 'Lucifer's sin of pride'37 at being so judgemental about their behaviour.

Occasionally, however, Michael's struggle with his ethnicity displaces his near fixation on religion. This is encapsulated in the tension between his admiration for certain English qualities, such as tolerance, and his refusal to conform to English conventions because of the anti-Irish prejudice he encounters. The latter is graphically demonstrated during an exercise at school when, required to recite a poem aloud to the rest of his class, Michael pronounces the word 'thing' in the Irish manner as 'ting' and is repeatedly scolded and beaten by the teacher for doing so. ${ }^{38}$ Rather than correcting his pronunciation, Michael stubbornly refuses to conform to the 'King's English', reciting to himself the words of a song about the Irish revolutionary leader Robert Emmet in order to endure the ordeal. By exploring these contradictory impulses, Naughton reveals how a dual sense of English and Irish affiliation is publicly and painfully negotiated by Michael, and how he eventually learns to deploy it strategically in different circumstances.

The Streets of Ancoats (1985) by Malcolm Lynch (1923-94) is an autobiographical novel with similar concerns in a comparable setting, this time an Irish neighbourhood in Manchester in the late 1920s. Catholicism once again plays a primary role in the story, with numerous references to the sacraments of Confession and Holy Communion, religious vocations, and sectarian gangs. Nine-year-old Kevin is more self-confident about his ethnicity than Michael M'Cloud, however, something which may be due to his growing up in a more distinctly Irish environment. This is vividly illustrated by a classroom scene which is uncannily similar to the one in One Small Boy. Kevin, like Michael, is physically punished by the teacher for insubordination. But in this novel, rather than humiliating the boy for having an Irish background, the teacher ameliorates the shame he feels in front of his classmates by drawing their attention to the historical contribution of Irish labourers to the physical infrastructure of their region: 
'The Irish have been coming to Manchester for three hundred years. Their muscles and tenacity built the first railway station in the world, in this town. Against impossible odds of marshes and swamps they put the first ever railway line from here to Liverpool for Stephenson's Rocket to pull passengers on. Right now, they're building a magnificent library in Peter's Square, where Peterloo took place. In the Great War, (p. 474) which isn't all that long ago, the Manchester Regiment was recruited almost exclusively from the Ancoats Irish-yes, the Ancoats Irish. So the Irish may claim this as an Irish town.'39

Compared to most fictional accounts of Irish life in England, Lynch's novel is also unusual for its attention to cross-cultural interactions between immigrant groups. In Lynch's Ancoats, the Irish and the Italian communities not only share a common neighbourhood but also a religion, which is variously a source of tension, comedy, and pathos. ${ }^{40}$ In a touching scene in the opening chapter, Kevin puzzles over his ethnicity when attracted to Vera, an Italian neighbour who 'was not a bit like the white-faced, freckled, red-haired Irish girls whom he normally threw half-bricks at'. ${ }^{41}$ Kevin's concern that he may not be permitted to marry Vera when he grows up reflects the influence of his national distinctiveness, but his friends' reassurance that 'it would be okay because she was a Catholic, even though she was not Irish', ${ }^{42}$ tellingly demonstrates how a communal form of religious allegiance plays a key role in the development of his ethnic consciousness.

After London, the centre of Irish life in England most often represented in fiction is Liverpool. A key example of this is a series of short stories by Moy McCrory (1953-) collected in The Water's Edge and Other Stories (1985), Bleeding Sinners (1988), and Those Sailing Ships of His Boyhood Dreams (1991). Most of these stories are set in the decades immediately after the Second World War and revolve around the lives of middle-aged workingclass Catholic women, the majority of whom, judging from their surnames, are either Irish-born or of Irish descent. The stories are told from a firmly feminist perspective and with a sense of humour often associated with the city in which they are set. ${ }^{43}$ Unlike other major English cities, a marked sectarian divide between Catholics and Protestants persisted in Liverpool until the mid-twentieth century. As a consequence, religion in McCrory's work is a profoundly public marker of ethnic affiliation. This is reflected in stories such as 'Last Judgement' (1985), 'New Blood' (1985), and 'The Wrong Vocation' (1991), which playfully critique the effects of Catholic indoctrination on Liverpool Irish children. 'Touring Holiday' (1985), on the other hand, signals a shift towards more personal preoccupations and has a more distinctly Irish dimension. It concerns a teenager who visits the country of her parents' birth and, for the first time, confronts her uncertain sense of national identity. Travelling there with (p. 475) her family's English neighbours, the girl initially identifies as English. However, as a consequence of her neighbours' anti-Irish attitudes and sneering provocations about her Irish habits, she returns home with a radically different sense of belonging to the one that she had set out with.

A visit or sojourn in Ireland is a common device used by authors to present characters' reevaluations of the English and Irish aspects of their identities, ${ }^{44}$ and bears some resemblance to the journeys made by the English-born offspring of absentee Anglo-Irish land- 
lords discussed earlier. L. T. Meade's The Home of Silence (1890) and Katharine Tynan's The River (1929) are early examples of this subgenre. Unusually for a novel about the Irish in England, The River is set in a rural location, in this case a fictionalized village in Lincolnshire. ${ }^{45}$ However, it is during the course of her alternating stays between there and the west of Ireland that Kitty Adair, a woman with mixed Catholic and Protestant parentage, learns to successfully negotiate the boundaries of religious as well as national identity. In this regard, Kitty mirrors the personality of her author, whose peripatetic lifestyle informed the preoccupations of her novels. ${ }^{46}$

An important development in recent years has been the emergence of a body of work exploring the lives of mixed-race Irish people growing up in England. One of the first examples of this trend is Lara (1997), a verse novel by London-born Bernardine Evaristo (1959-). Lara is raised in Woolwich in the 1960s and 1970s, and the novel charts her family history, in richly evocative imagery, from the late eighteenth century to the present day. As well as having German, Brazilian, and Nigerian roots, Lara is fourth-generation Irish on her mother's side. Despite her distant Irish origins, and their occlusion by successive generations of Englishness, the first half of the novel traces Lara's Irish ancestry back to the Great Famine in Tipperary. In doing so, it demonstrates how an awareness of a deeply buried family history can leave profound impressions on an individual's sense of identity. This is echoed in the plurality of literary genres and forms that Evaristo draws upon to weave the historical texture of the novel, suggesting that any single narrative mode is insufficient to adequately reflect her heroine's multiple sense of belonging. The novel also reflects a broader transition within the subgenre of Irish multigenerational fiction, away from the communal contexts of identity formation towards characters' more singular searches for a sense of self.

In terms of literary form, Vauxhall (2013), the debut novel by London-born Irish-Nigerian Gabriel Gbadamosi (1961-), takes a more conventional approach to mixed-race Irishness. Whereas in Lara, a working-class south London neighbourhood is the site of a centuriesdeep excavation of ethnic heritage, in Vauxhall, a similar environment is the anchor for a first-person realist text set in the 1970s, in which the action is (p. 476) played out within the confines of its immediate location. Yet its young protagonist, Michael, embarks on a no less demanding journey of discovery than Lara as he learns about his Irish and Nigerian family inheritance. This takes place while his inner-city neighbourhood is being demolished to make way for new tower blocks in a London struggling to adjust to the realities of a post-imperial multicultural dispensation. The effects of this are evident in the abject confusion and marginalization the boy feels as a consequence of the sometimes brutal racism he and his family experience. Michael's mother, who is white and might therefore be considered an insider in British culture, is nevertheless treated as an outsider, not only because she is Irish but also because she is married to a Nigerian man. In one episode, she is subject to racial abuse by a local street vendor and an elderly passer-by, the former of whom calls her a 'black man's mattress' ${ }^{47}$ Meanwhile, the fact that neither of them is even prepared to acknowledge Michael's presence at the scene provokes the following reaction from the boy: 'It was like I was a wooden post. They were treating me like I wasn't real.... "I'm a real boy," I said. They both turned to look at me, but it didn't 
make any difference, they looked at each other and shook their heads and turned away. ${ }^{48}$ This passage exemplifies one of the novel's strengths: its evocation of the boy narrator's mounting incredulity while growing up in a contested cultural environment where racism is blatant and endemic.

A similar mother-son relationship is at the heart of My Name is Leon (2016), the debut novel by Birmingham-born Kit de Waal (pseudonym of Mandy Theresa O'Loughlin, 1960-), daughter of an Irish mother and an African-Caribbean father. Set against the backdrop of the 1981 Birmingham riots, it is a first-person account by a mixed-race eightyear-old boy who is under the foster care of Maureen, an Irish woman. ${ }^{49}$ Like Gbadamosi's young protagonist, Leon experiences casual racism on a daily basis, something with which Maureen and her sister Sylvia try to help him come to terms. No less crucial to Leon's informal education are two surrogate father figures: Tufty, an AfroCaribbean man who informs him about the provocative police tactics against black people prior to the riots, and Mr Devlin, from whom he learns about the historical reasons for the Irish republican hunger strikes taking place at the time. While both characters are secondary protagonists, their influential role in the novel subtly draws attention to the fact that issues of colour and ethnicity in multicultural England cannot be reduced to a simple matter of black and white. Rather, the novel highlights how the country's cultural heterogeneity is often prone to being overwritten by an assumed hegemonic white Englishness. ${ }^{50}$ By revisiting the politics of Anglo-Irish allegiance explored in earlier fiction about the Irish in England, this novel of mixed-race Irishness ploughs an old furrow (p. 477) in terms of its postcolonial preoccupations, while unearthing new and challenging dimensions at every turn.

The prose fiction examined in this chapter explores how the processes of migrant adjustment to a new society are mediated under differing historical and political conditions through a variety of cultural signifiers, including nationality, religion, race, and class. It is notable also for its formal diversity, reflecting and contributing to developments in Irish prose literature more generally, from epistolary nineteenth-century modes, through various forms of twentieth-century realism and modernism, to contemporary metafictional and omni-generic narratives. However, the primary critical purpose of this chapter has been to identify and analyse predominant themes. Here, surprising commonalities are apparent not only within but between the categories of fiction examined. This is true even across works which feature ostensibly disparate cohorts of Irish migrants. One example of this is the similarity between the anomalous position in English society of the largely privileged Anglo-Irish protagonists of nineteenth-century fiction and that of the predominantly working-class characters of Irish descent in fiction from later eras. Particularly striking are the disjunctures of cultural allegiance between parents and their offspring, regardless of when or where the novel or short story is set. The emergence of a subgenre concerned with mixed-race Irish people in England further enhances the range of the canon by raising questions about the diverse components that make up diasporic identities in the contemporary period. Yet the role played here by race and colour is in many 
ways similar to that played by religion and class in the working-class Irish fictions set in the north of England in the early twentieth century.

Notwithstanding its numerous specificities, therefore, these continuities highlight how remarkably interconnected this literature is. Its most significant feature over the course of the last 200 years is the transition from work with a predominantly public-facing and sometimes didactic motivation to texts that are primarily inward-looking and psychological in complexion. Of course, no single text is ever entirely one or the other, and it is frequently the dynamic tension between these poles which provides such rich insights into the lives and preoccupations of its characters. As writers adopt new modes and genres in order to capture the experience of future generations of Irish migrants in England, what is unlikely to change is the essential purpose of prose fiction to provide unique insights into the relationship between society and the individual. Moreover, the fiction of the Irish in England will surely continue to demonstrate how reflecting the 'true face' of Irish migration can be an unpredictable yet engrossing narrative venture for both authors and their readers.

\section{Further Reading}

Arrowsmith, Aidan. 'Inside-Out: Literature, Cultural Identity and Irish Migration to England'. In Ashok Bery and Patricia Murray (eds), Comparing Postcolonial Literatures: Dislocations. Basingstoke: Palgrave, 2000: 59-69.

Bolger, Dermot. 'Foreword'. In Dermot Bolger (ed.), Ireland in Exile: Irish Writers Abroad. Dublin: New Island, 1993: 7-10.

(p. 478) Duffy, Patrick. 'Literary Reflections on Irish Migration in the Nineteenth and Twentieth Centuries'. In Russell King, John Connell, and Paul White (eds), Writing Across Worlds: Literature and Migration. London: Routledge, 1995: 20-38.

Harte, Liam (ed.). The Literature of the Irish in Britain: Autobiography and Memoir, 17252001. Basingstoke: Palgrave Macmillan, 2009.

Herron, Tom (ed.). Irish Writing London, Volume 1: Revival to the Second World War. London: Bloomsbury, 2013.

Herron, Tom (ed.). Irish Writing London, Volume 2: Post-War to the Present. London: Bloomsbury, 2013.

Hughes, Eamonn. '“Lancelot's Position”: The Fiction of Irish-Britain'. In A. Robert Lee (ed.), Other Britain, Other British: Contemporary Multicultural Fiction. London: Pluto Press, 1995: 142-60.

McWilliams, Ellen. Women and Exile in Contemporary Irish Fiction. London: Palgrave Macmillan, 2013. 
Murphy, James H. Irish Novelists and the Victorian Age. Oxford: Oxford University Press, 2011.

Murray, Tony. London Irish Fictions: Narrative, Diaspora and Identity. Liverpool: Liverpool University Press, 2012.

O’Brien, George. 'The Aesthetics of Exile'. In Liam Harte and Michael Parker (eds), Contemporary Irish Fiction: Themes, Tropes, Theories. Basingstoke: Macmillan, 2000: 35-55.

Standlee, Whitney. 'Power to Observe': Irish Women Novelists in Britain, 1890-1916. Bern: Peter Lang, 2015.

Ward, Patrick. Exile, Emigration and Irish Writing. Dublin: Irish Academic Press, 2002.

\section{Notes:}

$\left.{ }^{1}\right)$ Liam Ryan, 'Irish Emigration to Britain since World War II', in Richard Kearney (ed.), Migrations: The Irish at Home and Abroad (Dublin: Wolfhound Press, 1990), 46.

$\left({ }^{2}\right)$ Some of these excluded texts are referred to here in passing, while others are critiqued in one or more of the volumes in the Further Reading section below. For the broader context of scholarly engagement with the critical and semantic parameters of Irish migrant culture, see Aidan Arrowsmith (ed.), Irish Studies Review. Special Issue: Irishness in Britain 14, no. 2 (2006); Piaras Mac Éinrí and Tina O’Toole (eds), Éire-Ireland. Special Issue: New Approaches to Irish Migration 47, nos. 1-2 (2012); and Ellen McWilliams and Tony Murray (eds), Irish Studies Review. Special Issue: Irishness and the Culture of the Irish Abroad 26, no. 1 (2018).

( $\left.{ }^{3}\right)$ See, for instance, Richard Head, The English Rogue (1665), Thomas Amory, The Life of John Buncle, Esq. (1756), and Charles Johnstone, The Adventures of Anthony Varnish (1786). For a critique of such novels, see Derek Hand, A History of the Irish Novel (Cambridge: Cambridge University Press, 2011), 24-59. For examples of recent historical novels by English-based Irish writers set before 1800, see Emma Donoghue, Slammerkin (2001) and Ronan Bennett, Havoc in its Third Year (2004).

$\left({ }^{4}\right)$ One of the best-known examples is the character of Phineas Finn in Anthony Trollope's Phineas Finn, the Irish Member (1869) and Phineas Redux (1874).

$\left({ }^{5}\right)$ For examples of fictional portrayals of the Irish in Scotland, see Patrick MacGill, Children of the Dead End: The Autobiography of a Navvy (1914) and Bernard MacLaverty, Grace Notes (1997). For examples of fictional, if peripheral, Irish characters in Wales, see Henry Digby Beste, Poverty and the Baronet's Family: An Irish Catholic Novel (1845) and Daniel Owen, Rhys Lewis (1885).

(6) Maria Edgeworth, The Absentee, ed. W. J. McCormack and Kim Walker (Oxford: Oxford University Press, 2001), 199. For a critique of this aspect of The Absentee, see Claire 
Connolly, A Cultural History of the Irish Novel, 1790-1829 (Cambridge: Cambridge University Press, 2012), 24-28.

$\left({ }^{7}\right)$ For a later novel which echoes this theme, see Katherine Cecil Thurston, The Gambler (1905).

$\left({ }^{8}\right)$ Charles Maturin, The Wild Irish Boy (London: Longman, Hurst, Rees, and Orme, 1808), vol. $2,311$.

(9) John Banim, The Anglo-Irish of the Nineteenth Century (London: Henry Colburn, 1828), vol. 3, 105-7.

$\left({ }^{10}\right)$ For further discussion of this issue, see Emer Nolan, Catholic Emancipations: Irish Fiction from Thomas Moore to James Joyce (Syracuse, NY: Syracuse University Press, 2007), 73-6.

(11) Mrs S. C. Hall, 'Kate Connor', in Sketches of Irish Character (London: Frederick Westley and A. H. Davis, 1831), 189-208.

(12) For a slightly earlier novel about an Irish clerk in London, see W. B. Yeats, John Sherman (1891).

(13) Shan F. Bullock, Robert Thorne: The Story of a London Clerk (London: T. Werner Laurie, 1907), vii.

(14) Ibid., 1.

(15) Elizabeth Bowen, The Heat of the Day (London: Penguin, 1962), 165-6.

$\left({ }^{16}\right)$ Elizabeth Bowen, 'Sunday Afternoon', in The Collected Short Stories of Elizabeth Bowen (London: Penguin, 1983), 620. Original emphasis.

$\left({ }^{17}\right)$ For an extended discussion of this topic, see Peter J. Conradi, Iris Murdoch: A Life (London: HarperCollins, 2001), 3-32.

(18) Iris Murdoch, Under the Net (London: Vintage, 2002), 7-8.

(19) Other England-based Irish characters in Murdoch's oeuvre include Tim Burke in The Sandcastle (1957), Martin Lynch-Gibbon in A Severed Head (1961), and Kate Gray and Gavin Fivey in The Nice and the Good (1968).

$\left({ }^{20}\right)$ William Trevor, 'Between Holyhead and Dun Laoghaire', Times Literary Supplement, 6 February, 1981, 131; R. F. Foster, 'The Irishness of Elizabeth Bowen', in Paddy and Mr Punch: Connections in Irish and English History (London: Allen Lane, 1993), 107.

(21) Michael W. Thomas, 'William Trevor's Other Island', Irish Studies Review 6, no. 2 (1998), 155. 
$\left.{ }^{22}\right)$ In the early to mid-nineteenth century, the topic of Irish women in England was also taken up by a number of English novelists. See Amelia Beauclerc, Alinda, or the Child of Mystery: A Novel (1812), Miss Mason, Kate Gearey, or Irish Life in London: A Tale of 1849 (1853), and William Harrison Ainsworth, Old Court: A Novel (1867).

(23) See Rolf Loeber and Magda Stouthamer-Loeber, 'Literary Absentees: Irish Women Authors in Nineteenth-Century England', in Jacqueline Belanger (ed.), The Irish Novel in the Nineteenth Century: Facts and Fictions (Dublin: Four Courts Press, 2005), 167-86 and Ciaran O'Neill and Mai Yatani, 'Women, Ambition, and the City, 1890-1910', in Anna Pilz and Whitney Standlee (eds), Irish Women's Writing, 1878-1922: Advancing the Cause of Liberty (Manchester: Manchester University Press, 2016), 100-20.

(24) See also Rosa Mulholland's Dunmara (1864), published under the pseudonym Ruth Murray, which concerns an Irish female artist in London.

$\left({ }^{25}\right)$ James H. Murphy, Irish Novelists and the Victorian Age (Oxford: Oxford University Press, 2011), 6.

(26) Despite this distinctly feminist turn, a reactionary impulse is evident in the plotlines and characterizations of Irish fiction in England well into the twentieth century. See, for example, Mrs Alexander, Kitty Costello (1904) and Dorothea Conyers, Rooted Out (1923).

(27) Sarah Grand, The Beth Book (Toronto: George N. Morang, 1897), 536.

$\left({ }^{28}\right)$ For a slightly later and more emphatically modernist novel about a vulnerable Irish person in London, see Pádraic Ó Conaire, Deoraíocht (1910).

$\left({ }^{29}\right)$ Heather Ingman, 'Aliens: London in Irish Women's Writing', in Tom Herron (ed.), Irish Writing London: Volume 2, Post-War to the Present (London: Bloomsbury, 2013), 53.

$\left({ }^{30}\right)$ For a novel which critically portrays this milieu from an Irish male point of view, see Michael Campbell, Oh, Mary, This London (1959).

(31) There is a distinct subgenre of fiction about Irish women's experiences of abortion in London. See, for instance, Maeve Binchy's 'Shepherd's Bush' in Central Line (1978),

Deirdre Shanahan's 'Dancehall' in Green Ink Writers: Anthology of Short Stories (1982), and Edna O’Brien's Down by the River (1996).

${ }^{32}$ ) There is insufficient space here to cover the expansive genre of popular family sagas which contains many characters of Irish descent in English society. Relevant works include James Hanley's The Furys Saga (1935-58), Catherine Cookson's Kate Hannigan (1950) and Fifteen Streets (1952), Martina Cole's Dangerous Lady (1992) and Maura's Game (2002), and Gilda O'Neill's A Bond of Fate Trilogy (2002-05).

( $\left.{ }^{33}\right)$ For critiques of this literature, see Liam Harte (ed.), The Literature of the Irish in Britain: Autobiography and Memoir, 1725-2001 (Basingstoke: Palgrave Macmillan, 2009) 
and Tony Murray, London Irish Fictions: Narrative, Diaspora and Identity (Liverpool: Liverpool University Press, 2012).

( $\left.{ }^{34}\right)$ See Philip Ullah, 'Second-generation Irish Youth: Identity and Ethnicity', New Community 12 (1985), 310-20.

$\left({ }^{35}\right)$ Avtar Brah, Cartographies of Diaspora: Contesting Identities (London: Routledge, 1996), 149.

$\left({ }^{36}\right)$ For a critique of Naughton's autobiographies, see Liam Harte, 'Migrant Memory: The Recovery of Self in the Autobiography of Bill Naughton', Critical Survey 8, no. 2 (1996), 168-77.

(37) Bill Naughton, One Small Boy (London: MacGibbon and Kee, 1957), 111.

(38) Ibid., 149-51.

(39) Malcolm Lynch, The Streets of Ancoats (London: Constable, 1985), 162. There is a sizeable subgenre of fiction about Irish construction workers in England which includes Walter Macken's I Am Alone (1949), J. M. O’Neill's Open Cut (1986), John B. Keane's The Contractors (1993), and Edna O’Brien's short story, 'Shovel Kings', in Saints and Sinners (2011).

$\left({ }^{40}\right)$ For a fictional account of an Irishman's interactions with the Jewish community in London, see French-Canadian Louis Hémon's Blind Man's Bluff, trans Arthur Richmond (1925).

$\left({ }^{41}\right)$ Lynch, The Streets of Ancoats, 13.

$\left({ }^{42}\right)$ Ibid., 14. For a fictional exploration of Irish-Italian interactions in nineteenth-century Liverpool, see John Denvir, The Brandons: A Story of Irish Life in England (1903).

$\left({ }^{43}\right)$ For short stories about similar themes set in London, see 'After the Dance' and 'Don't Give Nothing' in Bridget O'Connor's Here Comes John (1993).

(44) See, for instance, Maude Casey's Over the Water (1987), Brian Keaney's Family Secrets (1997), and Dermot Bolger's Father's Music (1998).

$\left({ }^{45}\right)$ For examples of texts set in other rural English locations, see L. T. Meade's Bashful Fifteen (1892), Dorothy Macardle's Uneasy Freehold (1941), Caroline Blackwood's Corrigan (1984), Maurice Leitch's Burning Bridges (1989), and Pauline McLynn's Missing You Already (2009).

$\left.{ }^{46}\right)$ See Whitney Standlee, 'Power to Observe': Irish Women Novelists in Britain, 18901916 (Bern: Peter Lang, 2015), 196.

(47) Gabriel Gbadamosi, Vauxhall (London: Telegram, 2013), 162.

$(48)$ Ibid. 
$\left({ }^{49}\right)$ For other texts which portray the experience of the Irish in the West Midlands, see Jonathan Coe's The Rotters' Club (2001), Anne Bennett's Pack Up Your Troubles (2000), Kit de Waal's The Trick of Time (2018), and William Trevor's aforementioned Felicia's Journey.

$\left.{ }^{(50}\right)$ For an examination of this topic, see Mary J. Hickman, Sarah Morgan, Bronwen Walter, and Joseph Bradley, 'The Limitations of Whiteness and the Boundaries of Englishness: Second-generation Irish Identifications and Positionings in Multiethnic Britain', Ethnicities 5, no. 2 (2005), 160-82.

\section{Tony Murray}

Tony Murray is Director of the Irish Writers in London Summer School and Curator of the Archive of the Irish in Britain at London Metropolitan University. He is the author of London Irish Fictions: Narrative, Diaspora and Identity (Liverpool University Press, 2012) and the editor, with Ellen McWilliams, of a 2017 Irish Studies Review special issue on Irishness and the culture of the Irish abroad. 